\title{
ANALISIS EFEKTIVITAS DAN KONTRIBUSI PAJAK RESTORAN TERHADAP PENDAPATAN ASLI DAERAH (PAD) KABUPATEN SEMARANG
}

\author{
Giffiany Fibri Setiawati, Christina Retno Gayatrie \\ Jurusan Akuntansi Program Studi Akuntansi Politeknik Negeri Semarang, Jl. \\ Prof. Sudarto, SH Tembalang Semarang 50275
}

\begin{abstract}
The final project is aimed to understand the influence of restaurant tax on local generated revenue (PAD) in Semarang Regency in 2012-2016. Locally generated revenue is one indicator to determined the local government's autonomy level. Local tax in Semarang Regency increase from year to year. This research is conducted in Badan Keuangan Daerah Kabupaten Semarang. The method used in this final project is the analysis of effectiveness and contribution of restaurant tax in locally generated revenues as well as a simple regression analysis and simple correlation analysis to find out whether there is relationship between these variables is coincidental or indeed a truly relationship. The results of the analysis suggest that the level of effectiveness of the restaurant tax is very effective and the contribution to the restaurant tax revenue in 2012 is Rp1.717.123.699, in 2013 is Rp2.624.555.733, in 2014 is Rp3.142.559.312 in 2015 is Rp4.289.087.988 and in 2016 is Rp6.408.249.069 The relationship between restaurant tax and locally generated revenue is positive meaning that increasing the amount of restaurant tax revenue will result increased revenue.
\end{abstract}

Keywords: Restaurant Tax, Locally Generated Revenue (PAD)

\begin{abstract}
Abstrak: Penelitian ini bertujuan untuk mengetahui pengaruh penerimaan pajak restoran terhadap PAD Kabupaten Semarang tahun 2012-2016, Pendapatan Asli Daerah merupakan salah satu indikator penentu derajat kemandirian suatu daerah. Pajak Daerah di Kabupaten Semarang nilainya semakin meningkat dari tahun ke tahun. Penelitian ini dilakukan pada Badan Keuangan Daerah Kabupaten Semarang. Metode analisis data yang digunakan adalah analisis efektivitas dan kontribusi Pajak Restoran terhadap pendapatan asli daerah serta analisis regresi sederhana dan korelasi sederhana untuk mengetahui pengaruh dan hubungan yang terjadi antara variabel-variabel tersebut adalah suatu kebetulan atau memang hubungan yang benar-benar. Hasil penelitian ini menunjukkan bahwa tingkat efektivitas penerimaan pajak restoran sangat efektif, besarnya kontribusi pajak restoran terhadap pendapatan asli daerah Kabupaten Semarang pada tahun 2012 sebesar Rp1.717.123.699 tahun 2013 sebesar Rp2.624.555.733 ,tahun 2014 sebesar Rp3.142.559.312 ,tahun 2015 sebesar Rp4.289.087.988 dan tahun 2016 sebesar Rp6.408.249.069 Terbukti bahwa hubungan antara pajak restoran dengan pendapatan asli daerah Kabupaten Semarang adalah positif artinya bertambahnya jumlah pajak restoran juga akan meningkatkan pendapatan asli daerah.
\end{abstract}

Kata Kunci: Pajak Restoran, Pendapatan Asli Daerah (PAD) 
PENDAHULUAN

Latar Belakang Masalah

Indonesia merupakan salah satu negara yang menganut sistem otonomi daerah dalam penyelenggaraan pemerintahannya. Dengan adanya otonomi daerah, daerah memiliki hak dan kewajiban untuk mengatur daerahnya sendiri tetapi masih tetap dikontrol oleh pemerintah pusat serta sesuai dengan peraturan perundangundangan yang berlaku. Diharapkan dengan adanya pelaksanaan otonomi daerah, masyarakat akan memiliki kesejahteraan yang meningkat, hal itu dikarenakan pembangunan yang ada diberbagai daerah otonom disesuaikan dengan kebutuhannya. Hal itu akan berbanding terbalik jika pemerintahan diserahkan kepada pemerintah pusat bukan pemerintah daerah, pemerintah pusat tidak akan cermat terhadap berbagai macam kebutuhan yang ada di masing-masing daerah. Hal itu disebabkan oleh banyaknya daerah yang ada di Indonesia dan belum ada pemerintah yang mengaturnya.

Akhir-akhir ini masyarakat Indonesia cenderung menganut budaya konsumtif. Salah satunya merupakan konsumtif dalam mengkonsumsi makanan yaitu masyarakat lebih memilih jenis makanan fastfood atau cepat saji daripada makanan yang dibuat secara konvensional. Hal ini disebabkan karena masyarakat beranggapan bahwa makanan cepat saji lebih efisien dalam menghemat waktu, selain itu dengan mengkonsumsi makanan cepat saji mereka dianggap lebih berkelas dan modern. Dengan adanya hal tersebut, menyebabkan pengusaha makanan saling bersaing untuk menciptakan suatu inovasi makanan yang menarik dan sesuai untuk selera masyarakat. Tidak dipungkiri, banyaknya pelaku usaha di bidang makanan ikut serta meningkatkan jumlah tempat makan seperti, restoran, rumah makan, maupun café. Banyaknya pengusaha makanan dan perolehan omzetnya yang cukup tinggi secara tidak langsung membantu pembangunan daerah di Indonesia.

Meningkatnya pengusaha makanan di Kabupaten Semarang membuat mereka berlomba-lomba untuk membuka usaha makanan guna memenuhi kebutuhan masyarakat sekitar. Hal itu mengakibatkan bertambahnya jumlah tempat makan di Kabupaten Semarang. Selain itu omzet penjualan makanan tersebut juga mengalami kenaikan yang sebagian besar diperoleh dari tempat makan seperti restoran, rumah makan dan catering. Dengan adanya peningkatan omzet penjualan makanan didaerah Kabupaten Semarang, secara tidak langsung juga berdampak pada peningkatan pendapatan pajak restoran di daerah tersebut.

Tujuan

Tujuan dari penelitian ini akan dikaitkan dengan perumusan masalah yang telah di kemukakan, yaitu untuk menghitung tingkat efektivitas yang dicapai Pajak Restoran Kabupaten Semarang Tahun 20122016 dan untuk menghitung besarnya kontribusi Pajak Restoran terhadap Pendapatan Asli Daerah Kabupaten Semarang Tahun 2012-2016.

\section{TINJAUAN PUSTAKA}

\section{Definisi Pajak dan Unsur Pajak}

Menurut Mardiasmo (2011:1) pajak adalah iuran wajib rakyat kepada kas negara berdasarkan undang-undang tanpa mendapat timbal balik secara langsung dan digunakan untuk membiayai pengeluaran umum negara.

Dari definisi tersebut, dapat disimpulkan bahwa pajak memiliki unsur-unsur:

1. Iuran dari rakyat kepada Negara

Yang berhak memungut pajak hanyalah Negara. Iuran tersebut berupa uang (bukan barang).

2. Berdasarkan Undang-Undang

Pajak dipungut berdasarkan atau dengan kekuatan undang-undang serta aturan pelaksanaannya.

3. Tanpa timbal jasa atau kontraprestasi dari negara yang secara langsung dapat ditunjukkan. Dalam pembayaran pajak tidak dapat ditunjukkan adanya kontraprestasi individual oleh pemerintah.

4. Digunakan untuk membiayai rumah tangga negara, yakni pengeluaranpengeluaran yang bermanfaat bagi masyarakat luas.

\section{Fungsi Pajak}

Menurut Mardiasmo (2011:1) terdapat dua fungsi pajak yaitu:

1. Fungsi Budgetair

Pajak sebagai sumber dana pemasukan bagi pemerintah untuk membiayai pengeluaran negara.

2. Fungsi Mengatur (regulerend)

Pajak sebagai alat untuk mengatur dalam pelaksanaan kebijaksanaan pemerintah di bidang sosial dan ekonomi. 


\section{Teori-Teori yang Mendukung Pemungutan Pajak}

Menurut Mardiasmo (2011:3) beberapa teori yang menjelaskan alasan Negara untuk memungut pajak. Teori-teori tersebut antara lain:

1. Teori Asuransi

Membayar pajak diibaratkan sebagai premi asuransi karena memperoleh timbal balik berupa jaminan perlindungan dari negara.

2. Teori Kepentingan

Pembagian beban pajak didasarkan pada kepentingan masing-masing orang. Semakin besar kepentingan seseorang terhadap negara, semakin besar pajak yang harus dibayarkan.

3. Teori Daya Pikul

Beban pajak harus dibayar sesuai dengan daya pikul masing-masing orang. Untuk mengukur daya pikul dapat digunakan 2 pendekatan yaitu:

a. Unsur objektif, berpedoman pada besarnya penghasilan atau kekayaan yang dimiliki oleh seseorang.

b. Unsur subjektif, berpedoman pada kebutuhan materiil yang harus dipenuhi seseorang.

4. Teori Bakti

Membayar pajak diibaratkan sebagai bukti bakti rakyat terhadap negara nya, maka rakyat harus menyadari bahwa membayar pajak merupakan kewajiban.

5. Teori Asas Daya Beli

Memungut pajak diartikan menarik daya beli rumah tangga rakyat untuk rumah tangga negara, kemudian akan disalurkan kembali kepada masyarakat guna memelihara kehidupan masyarakat.

\section{Pengelompokkan Pajak}

Menurut Mardiasmo (2011:5) berbagai jenis pajak dapat dikelompokkan menurut golongan, menurut sifat, dan menurut lembaga pemungutan. Berikut pengelompokkannya:

1. Menurut Golongannya

a. Pajak langsung, pajak yang tidak dapat dibebankan kepada pihak lain.

Contoh: Pajak Penghasilan.

b. Pajak tidak langsung, yaitu pajak yang dapat dilimpahkan kepada pihak lain.

Contoh: Pajak Pertambahan Nilai.

2. Menurut Sifatnya a. Pajak subjektif, yaitu pajak yang memperhatikan keadaan diri Wajib Pajak.

Contoh: Pajak Penghasilan.

b. Pajak objektif, yaitu pajak yang tidak memperhatikan keadaan diri Wajib Pajak.

Contoh: Pajak Pertambahan Nilai dan Pajak Penjualan atas Barang Mewah.

3. Menurut Lembaga Pemungutnya

a. Pajak pusat, yaitu pajak yang dipungut oleh pemerintah pusat dan digunakan untuk membiayai pengeluaran - pengeluaran negara.

Contoh: Pajak Penghasilan, Pajak Pertambahan Nilai dan Pajak Penjualan atas Barang Mewah, dan Bea Materai.

b. Pajak daerah, yaitu pajak yang dipungut oleh pemerintah daerah dan digunakan untuk membiayai pengeluaran - pengeluaran daerah.

Pajak daerah terdiri atas:

1) Pajak Provinsi, contoh: Pajak Kendaraan Bermotor dan Pajak Rokok.

2) Pajak Kabupaten/Kota, contoh: Pajak Hotel, Pajak Restoran, dan Pajak Hiburan.

Tata Cara Pemungutan Pajak

Menurut Mardiasmo (2011:6) tata cara pemungutan pajak terdiri atas stelsel pajak, asas pemungutan pajak, dan sistem pemungutan pajak.

\section{Stelsel Pajak}

1. Stelsel nyata (riel stelsel)

Pemungutan pajak yang didasarkan pada kenyataan atau penghasilan yang sesungguhnya diterima oleh wajib pajak, oleh karena itu besarnya pajak yang terutang diperhitungkan pada akhir tahun pajak.

2. Stelsel anggapan (fictieve stelsel)

Pemungutan pajak yang didasarkan pada anggapan sesuai peraturan perundang-undangan yang berlaku. Besarnya pajak yang terutang ditentukan pada awal tahun, sehingga pajak yang terutang ditentukan dari penghasilan yang diterima tahun lalu dan besaran pajak yang terutang pun sama.

3. Stelsel campuran

Pemungutan pajak yang menggunakan stelsel nyata dan anggapan. Pada awal tahun besarnya pajak yang terutang disamakan dengan pajak terutang 
tahun lalu. Pada akhir tahun dihitunglah pajak sebenarnya yang terutang, apabila besarnya pajak terutang lebih besar dari pajak yang telah ditentukan diawal tahun maka wajib pajak harus membayar kekurangan pajak tetapi jika besarnya pajak terutang lebih kecil dari pajak yang telah dibayarkan, maka wajib pajak harus meminta kelebihan pajak tersebut.

Asas Pemungutan Pajak

Menurut Mardiasmo (2011:7) asas pemungutan pajak terdiri dari:

1. Asas domisili (asas tempat tinggal)

Pemungutan pajak didasarkan pada penghasilan seluruh wajib pajak yang bertempat tinggal di wilayah tersebut, baik dari dalam negeri ataupun luar negeri.

2. Asas sumber

Pemungutan pajak didasarkan pada penghasilan seluruh wajib pajak yang bersumber dari wilayah tersebut.

3. Asas kebangsaan

Pemungutan pajak didasarkan pada kebangsaan suatu negara.

Sistem Pemungutan Pajak

Menurut Mardiasmo (2011:7) sistem dalam pemungutan pajak terdiri dari:

1. Official Assessment System

Suatu sistem dimana besarnya pajak terutang ditentukan oleh pemerintah (fiskus).

2. Self Assessment System

Suatu sistem dimana Wajib Pajak diberikan kewenangan untuk menentukan sendiri besarnya pajak yang terutang.

3. With Holding System

Suatu sistem dimana besarnya pajak yang terutang ditentukan oleh pihak ketiga (bukan fiskus dan bukan Wajib Pajak).

Definisi Pendapatan Daerah

Undang - Undang Nomor 23 Tahun 2014 tentang Pemerintahan Daerah menyatakan bahwa "Pendapatan daerah adalah semua hak daerah yang diakui sebagai penambah nilai kekayaan bersih dalam periode tahun anggaran yang bersangkutan." Pendapatan daerah oleh pemerintah daerah digunakan sebagai sumber belanja kebutuhan daerah dan pembiayaan daerah yang telah ditetapkan dalam Anggaran Pendapatan dan Belanja Daerah (APBD).

Sumber Pendapatan Daerah
Menurut Abdul Halim (2011:101) pendapatan daerah dibagi menjadi:

1. Pendapatan Asli Daerah (PAD)

a. Pajak Daerah Jenis pendapatan pajak dibagi menjadi dua yaitu:

1) Pajak Provinsi meliputi:

2) Pajak Kabupaten/Kota meliputi:

b. Retribusi Daerah

Jenis pendapatan retribusi dibedakan menjadi:

1) Retribusi Jasa Umum

2) Retribusi Jasa Usaha

3) Retribusi Perizinan Tertentu

c. Hasil Pengelolaan Kekayaan Milik

Jenis pendapatan ini mencakup:

1) Bagian Laba atas penyertaan modal pada perusahaan milik daerah/BUMD.

2) Bagian Laba atas penyertaan modal pada perusahaan milik Negara/BUMN.

3) Bagian Laba atas penyertaan modal pada perusahaan milik swasta atau kelompok usaha masyarakat.

d. Lain - lain PAD yang Sah

2. Pendapatan Transfer

Pendapatan daerah yang diperoleh dari kekuasaan pemerintah di atasnya. Dibedakan menjadi tiga jenis yaitu:

a. Transfer pemerintah pusat-dana perimbangan, meliputi:

1) Dana bagi hasil pajak

2) Dana bagi hasil bukan pajak (sumber daya alam)

3) Dana alokasi umum

4) Dana alokasi khusus

b. Transfer pemerintah pusat lainnya, meliputi:

1) Dana otonomi khusus

2) Dana penyesuaian

c. Transfer pemerintah provinsi, meliputi:

1) Pendapatan bagi hasil pajak

2) Pendapatan bagi hasil lainnya

3. Lain - lain Pendapatan yang Sah

Lain-lain pendapatan yang sah dibedakan menjadi:

a. Pendapatan hibah

b. Pendapatan dana darurat

c. Pendapatan lainnya.

Definisi Pajak Daerah

Mardiasmo (2011:12) menyatakan bahwa:

Pajak daerah yang selanjutnya disebut pajak, adalah kontribusi wajib kepada Daerah yang terutang oleh orang pribadi atau badan yang bersifat 
memaksa berdasarkan Undang-Undang, dengan tidak mendapatkan imbalan secara langsung dan digunakan untuk keperluan Daerah bagi sebesarbesarnya kemakmuran rakyat.

Jenis - Jenis Pajak Daerah

Menurut Undang-Undang Nomor 28 tahun 2009, jenis pajak terdiri dari:

1. Jenis Pajak Provinsi terdiri atas:

a. Pajak kendaraan bermotor

b. Bea balik nama kendaraan bermotor

c. Pajak bahan bakar kendaraan bermotor

d. Pajak air permukaan

e. Pajak rokok

2. Jenis Pajak Kabupaten/kota terdiri atas:

a. Pajak hotel

b. Pajak restoran

c. Pajak hiburan

d. Pajak reklame

e. Pajak penerangan jalan

f. Pajak mineral bukan logam dan batuan

g. Pajak parkir

h. Pajak air tanah

i. Pajak sarang burung walet

j. Pajak bumi dan bangunan perdesaan dan perkotaan

k. Bea perolehan hak atas tanah dan bangunan

Pemungutan Pajak Daerah

Undang-Undang Nomor 28 Tahun 2009 tentang Tata Cara Pemungutan Pajak Daerah Kabupaten/Kota menyatakan bahwa:

1. Pemungutan Pajak dilarang diborongkan.

2. Setiap Wajib Pajak wajib membayar Pajak yang terutang berdasarkan surat ketetapan pajak atau dibayar sendiri oleh Wajib Pajak berdasarkan peraturan perundang-undangan perpajakan.

3. Wajib Pajak yang memenuhi kewajiban perpajakan berdasarkan penetapan Kepala Daerah dibayar dengan menggunakan SKPD (Surat Ketetapan Pajak Daerah) atau dokumen lain yang dipersamakan.

4. Dokumen lain yang dipersamakan berupa karcis dan nota perhitungan.

5. Wajib Pajak yang memenuhi kewajiban perpajakan sendiri dibayar dengan menggunakan SPTPD (Surat Pemberitahuan Pajak Daerah), SKPDKB (Surat Ketetapan Pajak Daerah Kurang Bayar) dan/atau
SKPDKBT (Surat Ketetapan Pajak Daerah Kurang Bayar Terutang).

\section{Definisi Pajak Restoran}

Undang-Undang Nomor 28 Tahun 2009 menyatakan bahwa "Pajak restoran adalah adalah pajak atas pelayanan yang disediakan oleh restoran". Pemungutan pajak restoran tidak hanya dikenakan pada pelayanan atas penjualan makanan atau minuman yang diusahakan oleh restoran, namun mencakup juga usaha rumah makan, kafetaria, kantin, warung, bar, dan jasa boga atau catering.

\section{Objek Pajak Restoran}

Menurut Peraturan Daerah Kabupaten Semarang Nomor 10 Tahun 2010, objek pajak restoran merupakan pelayanan atas penjualan makanan atau minuman yang dikonsumsi oleh pembeli baik dikonsumsi direstoran tersebut atau ditempat lain.

\section{Pengecualian Objek Pajak Restoran}

Menurut Peraturan Daerah Kabupaten Semarang Nomor 10 Tahun 2010, yang tidak dikenakan atau menjadi objek pajak restoran adalah pelayanan yang diberikan restoran atas penjualan makanan atau minuman dari restoran tersebut yang hasil penjualannya kurang dari Rp. 5.000.000,(lima juta rupiah) per bulan.

\section{Klasifikasi Restoran berdasarkan}

\section{Penggolongannya}

Kriteria standar usaha restoran dibagi sebagai berikut:

1. Restoran Non Bintang

2. Restoran Bintang Satu

3. Restoran Bintang Dua

4. Restoran Bintang Tiga

\section{Subjek Pajak Restoran}

Menurut Peraturan Daerah Kabupaten Semarang Nomor 10 Tahun 2010 yang dimaksud subjek pajak restoran adalah Wajib Pajak orang pribadi atau badan yang membeli atau mengkonsumsi makanan dan minuman yang disediakan oleh restoran tersebut.

\section{Wajib Pajak Restoran}

Peraturan Daerah Kabupaten Semarang Nomor 10 Tahun 2010 menjelaskan bahwa "Wajib Pajak Restoran adalah orang pribadi atau Badan yang mengusahakan restoran." Maksud dari mengusahakan restoran adalah pemilik ataupun pengelola dari restoran tersebut.

\section{Dasar pengenaan Pajak Restoran}

Peraturan Daerah Kabupaten Semarang Nomor 10 Tahun 2010 menerangkan bahwa "Dasar pengenaan Pajak Restoran adalah 
jumlah pembayaran yang diterima atau yang seharusnya diterima Restoran."

\section{Tarif Pajak Restoran}

Menurut Peraturan Daerah Kabupaten Semarang Nomor 10 Tahun 2010, tarif Pajak Restoran ditetapkan sebagai berikut:

1. Restoran dengan nilai penjualan lebih dari Rp 5.000.000,- (lima juta rupiah) sampai dengan Rp 15.000.000,- (lima belas juta rupiah) per bulan ditetapkan sebesar $5 \%$ (lima per seratus).

2. Restoran dengan nilai penjualan lebih dari Rp. 15.000.000,- (lima belas juta rupiah) per bulan ditetapkan sebesar 10 $\%$ (sepuluh per seratus).

Besaran pokok Pajak Restoran yang terutang dihitung dengan cara mengalikan tarif Pajak Restoran dengan dasar pengenaan Pajak Restoran.

Secara umum perhitungan Pajak Restoran menggunakan rumus berikut:

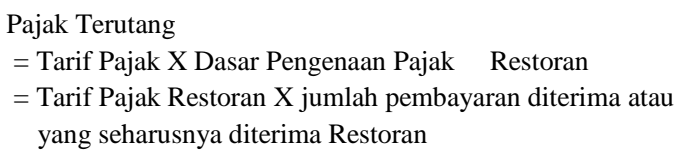

\section{Analisis Efektivitas}

Efektivitas merupakan indikator sederhana dari penilaian kinerja dari suatu organisasi. Menurut Abdul Halim (2011:L-6) "rasio efektivitas menggambarkan kemampuan pemerintah daerah dalam merealisasikan pendapatan asli daerah yang direncanakan dibandingkan dengan target yang ditetapkan berdasarkan potensi riil daerah."

\section{Analisis Kontribusi}

Menurut Kamus Besar Bahasa Indonesia "kontribusi berarti sumbangan", Diperlukan sumbangan guna mencapai tujuan yang besar. Analisis kontribusi digunakan untuk mengukur bagaimana sumbangan atau kontribusi suatu variabel pada variabel lain yang terkait. Dalam hal ini dibutuhkan kontribusi atau sumbangan dari pajak daerah untuk meningkatkan perolehan pendapatan asli daerah yang secara tidak langsung juga ikut meningkatkan pendapatan daerah.

\section{METODE PENELITIAN}

\section{Identifikasi Variabel}

Dalam penelitian ini terdapat dua variabel yang akan dianalisis, yaitu variabel terikat dan variabel bebas. Kedua variabel tersebut adalah:

a. Variabel Terikat (Variabel Dependen)

Variabel terikat (variabel yang dipengaruhi) adalah variabel yang nilainya dipengaruhi oleh variabel bebas.
$\mathrm{Y}=$ Pendapatan Asli Daerah

Kabupaten

Semarang

b. Variabel Bebas (Variabel Independen)

Variabel bebas (variabel yang mempengaruhi) adalah variabel yang menjadi sebab terpengaruhnya variabel terikat.

$\mathrm{X}=$ Pajak Restoran

\section{Klasifikasi data}

\section{Data Menurut Sifatnya}

Data menurut sifatnya terdiri dari:

a. Data Kualitatif

Menurut Fathor Rahman Utsman (2015:31) data kualitatif, yaitu data informasi yang berbentuk simbol verbal (simbol-simbol bahasa) yaitu berupa kata atau kalimat.

Data kualitatif yang digunakan berupa gambaran umum dan struktur organisasi dari Badan Keuangan Daerah Kabupaten Semarang.

b. Data Kuantitatif

Menurut Fathor Rahman Utsman (2015:32) data kuantitatif, yaitu data informasi yang berbentuk simbol-simbol angka. Data kuantitatif diperoleh melalui perhitungan atau pengukuran.

Data kuantitatif yang digunakan berupa data Laporan Realisasi Pendapatan Kabupaten Semarang dan data target serta realisasi Pajak Restoran Kabupaten Semarang tahun 2012-2016.

\section{Data Menurut Cara Memperolehnya}

Data menurut cara memperolehnya terdiri dari:

a. Data Primer

Menurut Fathor Rahman Utsman (2015:33) data primer, yaitu data yang diperoleh dari sumber pertama atau belum dilakukan pengolahan terlebih dahulu. Data primer merupakan data yang masih asli.

Data primer yang diperlukan berupa data mengenai jenis pajak daerah yang menjadi sumber pendapatan asli daerah Kabupaten Semarang.

b. Data Sekunder

Menurut Fathor Rahman Utsman (2015:33) data sekunder, yaitu data yang tidak diperoleh dari sumber pertama atau sudah dilakukan pengolahan terlebih dahulu.

Data sekunder yang dibutuhkan merupakan data Laporan Realisasi Pendapatan Kabupaten Semarang tahun 2012-2016.

Metode Pengumpulan Data 
Metode pengumpulan data yang diperlukan untuk memperoleh data yang akurat berupa:

a. Metode Wawancara

Menurut Burhan Bungin (2013:133) metode wawancara adalah cara memperoleh informasi dengan melakukan tanya jawab antara pewawancara dengan narasumber. Wawancara sangat berguna untuk memperoleh informasi dari narasumber secara cepat dan tepat.

Wawancara yang dilakukan guna mendapat informasi yang dibutuhkan berupa wawancara langsung dengan kepala bidang Pendapatan dan kepala bidang Pajak pada Badan Keuangan Daerah Kabupaten Semarang.

b. Metode Dokumenter

Menurut Burhan Bungin (2013:153) metode dokumenter adalah metode pengumpulan data dengan menelusuri data historis yang berbentuk dokumentasi yang menggambarkan peristiwa di masa lalu.

Metode dokumenter yang dilakukan berupa membaca dan mempelajari data Laporan Realisasi Pendapatan Kabupaten Semarang tahun 2012-2016 dan gambaran umum serta struktur organisasi Badan Keuangan Daerah Kabupaten Semarang.

\section{Metode Penulisan}

Metode Penulisan yang digunakan dalam penyusunan Tugas Akhir ini berupa:

a. Metode Deskripsi

Menurut Alek dan Achmad (2010:184) deskripsi yaitu metode penulisan dengan cara menggambarkan objek pengamatan yang diamati sesuai dengan keadaan sebenarnya.

Metode deskripsi yang diperlukan berupa gambaran umum dan struktur organisasi Badan Keuangan Daerah Kabupaten Semarang, serta profil Kabupaten Semarang.

b. Metode Eksposisi

Menurut Alek dan Achmad (2010:183) eksposisi yaitu metode penulisan dengan cara memaparkan informasi, penjelasan, keterangan atau pemahaman mengenai sesuatu yang belum diketahui pembaca.

Metode ini memaparkan hasil dari analisis efektivitas dan kontribusi Pajak Restoran terhadap Realisasi Pendapatan Asli Daerah Kabupaten Semarang. Metode ini juga digunakan untuk memaparkan hasil perhitungan yang terkait dalam Tugas Akhir.

\section{Metode Analisis Data}

Analisis Efektivitas Pajak Restoran

Kabupaten Semarang

Alat ukur atau indikator untuk melihat efektif atau tidaknya dalam penyerapan pajak daerah, berkaitan dengan kriteria penilaian terhadap tingkat efektivitas, maka kriteria penilaian efektivitas pemungutan pajak ditetapkan sebagai berikut:

Kriteria Penilaian Efektivitas

\begin{tabular}{|c|c|}
\hline $\begin{array}{c}\text { Klasifikasi } \\
\text { Efektivitas }\end{array}$ & Kriteria \\
\hline$>100 \%$ & Sangat Efektif \\
\hline $90-100 \%$ & Efektif \\
\hline $80-90 \%$ & Cukup Efektif \\
\hline $60-80 \%$ & Kurang Efektif \\
\hline$<60 \%$ & Tidak Efektif \\
\hline
\end{tabular}

Sumber: Departemen Dalam Negeri, Kepdagri No.690.900.327 Tahun 1996

Dalam pengukuran hasil tersebut maka diperlukan suatu cara untuk mengetahui bagaimana cara menilai kriteria tersebut. Perhitungan efektivitas menggunakan rumus sebagai berikut:

$$
\begin{aligned}
& \text { Efektivitas Pajak Restoran } \\
= & \frac{\text { Realisasi Pajak Restoran }}{\text { Target Pajak Restoran }} \times 100 \%
\end{aligned}
$$

Analisis Kontribusi Pajak Restoran terhadap

\section{Pendapatan Asli Daerah Kabupaten}

\section{Semarang}

Berhubungan dengan pajak restoran, analisis kontribusi digunakan untuk mengukur bagaimana kontribusi suatu variabel pada variabel lain yang terkait. Pajak restoran yang dikelola oleh Pemerintah Kabupaten Semarang akan diketahui bentuk penyerapan terhadap penerimaan pendapatan asli daerah tersebut dengan dilakukannya analisis kontribusi tersebut.

Perhitungan kontribusi Pendapatan Asli Daerah (PAD) dan pajak restoran dapat $\frac{\text { menggunakan rumus sebagai berikut: }}{\text { Kontribusi PAD }=}$ $\frac{\text { Pendapatan Asli Daerah }(R p)}{\text { Pendapatan Daerah }(R p)} X 100 \%$

Kontribusi Pajak Restoran $=$ $\frac{\text { Pajak Restoran }(R p)}{P A D(R p)} X 100 \%$ 
Rincian kriteria penilaian kontribusi ditampilkan sebagai berikut:

Kriteria Penilaian Kontribusi

\begin{tabular}{|c|c|}
\hline Klasifikasi Kontribusi & Kriteria \\
\hline $0,00 \%-10 \%$ & Sangat Kurang \\
\hline $10,10 \%-20 \%$ & Kurang \\
\hline $20,10 \%-30 \%$ & Sedang \\
\hline $30,10 \%-40 \%$ & Cukup Baik \\
\hline $40,10 \%-50 \%$ & Baik \\
\hline Diatas $50 \%$ & Sangat Baik \\
\hline
\end{tabular}

Sumber: Departemen Dalam Negeri, Kepdagri No.690.900.327 Tahun 1996

\section{Analisis Regresi Sederhana}

Menurut Danang Sunyoto (2011:9) analisis regresi adalah analisis yang digunakan untuk mengukur bagaimana pengaruh variabel bebas terhadap variabel terikat. Pengukuran pengaruh ini melibatkan satu variabel bebas (X) dan variabel terikat (Y), analisis regresi linier sederhana dirumuskan sфbagai berikut:

$$
Y=a+b X
$$

Keterangan :

$a=$ konstanta

$b=$ koefisien regresi untuk variabel $\mathrm{X}$

Dimana nilai $a$ dan $b$ dapat dicari dengan 2 rumus, yaitu:

$$
b=\frac{n(\Sigma X Y)(\Sigma X)(\Sigma Y)}{n\left(\Sigma X^{2}\right)-(\Sigma X)^{2}} \quad a=Y-b X
$$

atau

$$
a=\frac{\Sigma Y}{n}-b \frac{\Sigma X}{n}
$$

Keterangan:

$\mathrm{X}$ = variabel bebas

$\mathrm{Y}=$ variabel terikat

$\mathrm{a}=$ konstanta, merupakan jarak antara titik-titik potong garis regresi dengan sumbu vertikal terhadap 0 (titik asal) atau dengan kata lain besarnya nilai $\mathrm{Y}$ taksiran untuk $\mathrm{X}=0$

$\mathrm{b}=$ koefisien regresi, yaitu besar kecilnya variable $\mathrm{Y}$ akibat perubahan satu unit variabel $\mathrm{X}$

$\mathrm{n}=$ jumlah data/pengamatan

\subsubsection{Analisis Korelasi Sederhana}

Menurut Danang Sunyoto (2011:27) analisis korelasi adalah analisis yang digunakan untuk mengukur tingkat hubungan antara variabel bebas dan variabel terikat. Analisis korelasi sederhana dicari dengan rumus sebagai berikut:

$$
r=\frac{n\left(\sum X Y\right)-\left(\sum X\right)\left(\sum Y\right)}{\sqrt{\left.n\left(\sum X^{2}\right)-\left(\sum X\right)^{2}\right)} \sqrt{n\left(\sum Y^{2}\right)-\left(\sum Y\right)^{2}}}
$$

Keterangan :

$r=$ koefisien korelasi
$\mathrm{X}=$ variabel bebas

$\mathrm{Y}=$ variabel terikat

\begin{tabular}{|c|c|c|c|c|}
\hline TAHUN & $\begin{array}{c}\text { TARGET } \\
\text { (RP) }\end{array}$ & $\begin{array}{c}\text { REALISASI } \\
\text { (RP) }\end{array}$ & $\begin{array}{c}\text { EFEKTIVITAS } \\
(\%)\end{array}$ & \multirow[t]{2}{*}{ PREDIKAT } \\
\hline (1) & (2) & (3) & $(4)=(3):(2) \times 100$ & \\
\hline 2012 & 1.300 .000 .000 & 1.717 .123 .699 & 132,09 & Sangat Efektif \\
\hline 2013 & 2.612 .600 .000 & 2.624 .555 .733 & 100,46 & Sangat Efektif \\
\hline 2014 & 2.800 .000 .000 & 3.142 .559 .312 & 112,23 & Sangat Efektif \\
\hline 2015 & 3.800 .000 .000 & 4.289 .087 .988 & 112,87 & Sangat Efektif \\
\hline 2016 & 5.000 .000 .000 & 6.408 .249 .069 & 128,16 & Sangat Efektif \\
\hline & Rata - & & 117,16 & $\begin{array}{l}\text { Sangat } \\
\text { Efektif }\end{array}$ \\
\hline
\end{tabular}

$\mathrm{n}=$ jumlah data/pengamatan

\section{HASIL DAN PEMBAHASAN \\ Efektivitas Pajak Restoran Kabupaten \\ Semarang}

Sumber: Data sekunder yang diolah kembali, 2017

Dari tabel 4.10 dapat diketahui bahwa ratarata penerimaan pajak restoran tahun 2012 2016 bersifat sangat efektif dimana efektivitasnya melebihi $100 \%$ yaitu sebesar117,16\%. Hal ini membuktikan bahwa pemungutan pajak restoran sudah dilakukan secara efektif meskipun pernah terjadi penurunan efektivitas yang lumayan besar pada tahun 2012 sebesar 132,09\%

\begin{tabular}{|c|c|c|c|c|}
\hline TAHUN & $\begin{array}{c}\text { PAJAK } \\
\text { RESTORAN (RP) }\end{array}$ & PAD (RP) & KONTRIBUSI & \multirow{2}{*}{ PREDIKAT } \\
\hline (1) & (2) & (3) & $\begin{array}{c}(4)=(2):(3) X \\
100\end{array}$ & \\
\hline 2012 & 1.717.123.699 & 156.104 .007 .120 & 1,10 & Sangat Kurang \\
\hline 2013 & 2.624.555.733 & 215.679 .554 .472 & 1,22 & Sangat Kurang \\
\hline 2014 & 3.142 .559 .312 & 248.213 .019 .938 & 1,27 & Sangat Kurang \\
\hline 2015 & 4.289.087.988 & 278.851 .900 .617 & 1,54 & Sangat Kurang \\
\hline 2016 & 6.408 .249 .069 & 318.536 .051 .176 & 2,01 & Sangat Kurang \\
\hline \multicolumn{3}{|c|}{ Rata - Rata } & 1,43 & Sangat Kurang \\
\hline
\end{tabular}
menjadi 100,46\% pada tahun 2013 .

Kontribusi Pajak Restoran terhadap Pendapatan Asli Daerah Kabupaten Semarang

Sumber: Data sekunder yang diolah kembali, 2017

Dari tabel diatas dapat diketahui bahwa kontribusi Pajak Restoran terhadap Pendapatan Asli Daerah Kabupaten Semarang meningkat dari tahun ke tahun. Peningkatan tertinggi terjadi dari tahun 2015 ke tahun 2016 sebesar 0,47\%. Namun secara rata-rata kontribusi Pajak Restoran terhadap Pendapatan Asli Daerah Kabupaten Semarang hanya sebesar 1,43\% ,kecilnya kontribusi tersebut masuk kedalam predikat sangat kurang dalam berkontribusi.

\section{Analisis Regresi Sederhana}


Dari perhitungan analisis regresi ditemukan hasil konstanta (a) dan koefisien (b) adalah $\mathrm{a}=125.253 .128 .219$ dan $\mathrm{b}=$ 32,51. Jadi persamaan regresi dari rumus tersebut yaitu $\mathrm{Y}=125.253 .128 .219+$ 32,51X. Apabila variabel $\mathrm{X}=0$ maka variabel Y sebesar Rp125.253.128.219 Berikut ditampilkan dalam tabel 4.13 berupa penerapan hubungan antara Pajak Restoran dan Pendapatan Asli Daerah Kabupaten Semarang.

\section{Analisis Korelasi Sederhana}

Dari hasil analisis korelasi sederhana menyatakan bahwa hubungan antara Pajak Restoran (X) dan Pendapatan Asli Daerah (Y) bersifat positif, karena nilai korelasinya $(\mathrm{r}=0,95)$ berada tepat antara 0 dan 1 , atau $0<\mathrm{r}<1$ yang berarti hubungan antara Pajak Restoran dan Pendapatan Asli Daerah bersifat positif, searah dan sangat kuat. Apabila Pajak Restoran mengalami kenaikan maka Pendapatan Asli Daerah juga mengalami kenaikan, sedangkan apabila Pajak Restoran mengalami penurunan maka Pendapatan Asli Daerah juga mengalami penurunan.

\section{PENUTUP}

\section{Simpulan}

Hasil analisis efektivitas dan kontribusi Pajak Restoran terhadap Pendapatan Asli Daerah Kabupaten Semarang tahun 20122016 dapat disimpulkan sebagai berikut:

a. Tingkat efektivitas Pajak Restoran di Kabupaten Semarang tahun 2012-2016 memperoleh rata-rata kriteria sangat efektif dimana efektivitasnya lebih dari $100 \%$ yaitu sebesar $117,16 \%$ dari target yang dianggarkan pada tahun tersebut. Dibuktikan dengan prosentase pada tahun 2012 sebesar $132,09 \%$ dikategorikan sangat efektif, tahun 2013 dengan prosentase sebesar 100,46\% dikategorikan sangat efektif, tahun 2014 dengan prosentase sebesar 112,23\% dikategorikan sangat efektif, tahun 2015 dengan prosentase sebesar 112,87\% dikategorikan sangat efektif dan tahun 2016 dengan prosentase sebesar $128,16 \%$ dikategorikan sangat efektif.

b. Tingkat kontribusi Pajak Restoran terhadap Pendapatan Asli Daerah Kabupaten Semarang tahun 2012-2016 belum maksimal dan sangat kecil. Pada tahun 2012 prosentase sebesar 1,10\% termasuk kategori sangat kurang, tahun 2013 dengan prosentase sebesar 1,22\% termasuk kategori sangat kurang, tahun
2014 prosentase sebesar 1,27\% termasuk kategori sangat kurang, tahun 2015 prosentase sebesar 1,54\% termasuk kategori sangat kurang dan tahun 2016 prosentase sebesar 2,01\% termasuk kategori sangat kurang. Perolehan rata-ratanya sebesar 1,43\% atau kurang dari 10\%, sehingga dapat disimpulkan bahwa kontribusi Pajak Restoran Kabupaten Semarang sangat kurang terhadap peningkatan Pendapatan Asli Daerah di Kabupaten Semarang.

c. Hasil dari perhitungan analisis regresi dan analisis korelasi membuktikan bahwa hubungan antara Pajak Restoran dan Pendapatan Asli Daerah Kabupaten Semarang sangat positif dan saling mempengaruhi satu sama lain. Apabila terjadi peningkatan pada perolehan Pajak Restoran maka Pendapatan Asli Daerah Kabupaten Semarang juga ikut meningkat dan apabila terjadi penurunan pada Pajak Restoran maka Pendapatan Asli Daerah Kabupaten Semarang juga ikut menurun.

d. Kecilnya kontribusi Pajak Restoran terhadap Pendapatan Asli Daerah Kabupaten Semarang mungkin disebabkan karena Kabupaten Semarang kurang memperhatikan dan mempromosikan tempat wisata maupun penginapan yang ada di wilayahnya yang dapat membantu meningkatkan pendapatan restoran, sehingga secara tidak langsung hal tersebu mempengaruhi penerimaan Pajak Restoran bagi Pendapatan Asli Daerah Kabupaten Semarang.

\section{DAFTAR PUSTAKA}

Alek dan Achmad. 2011. Bahasa Indonesia untuk Perguruan Tinggi. Jakarta: Kencana Prenada Media Group.

Badan Pusat Statistik Kabupaten Semarang. 2016. Kabupaten Semarang Dalam Angka 2016. https://semarangkab.bps.go.id/website/p df_publikasi/Kabupaten-SemarangDalam-Angka-2016. (10 Juni 2017) (Internet)

Bungin, Burhan. 2013. Metodologi Penelitian Sosial dan Ekonomi. Edisi Pertama. Jakarta: Kencana Prenada Media Group.

Halim, Abdul dan Muhammad Syam Kusufi. 2011. Akuntansi Keuangan Daerah. Edisi 4. Jakarta: Salemba Empat. 
Karina, Nurul dan Novi Budiarso. 2016.

"Analisis Efektivitas dan Kontribusi Pajak Kendaraan Bermotor terhadap Pendapatan Asli Daerah Provinsi Gorontalo". Jurnal EMBA Universitas Sam Ratulangi Manado. https://media.neliti.com/media/publicatio ns/2942-ID-analisis-efektivitas-dankontribusi-pajak-kendaraan-bermotorterhadap-pendapatan. (10 Mei 2017). (Internet)

Mahmudi. 2016. Analisis Laporan Keuangan Pemerintah Daerah. Edisi Ketiga. Yogyakarta: UPP STIM YKPN.

Mardiasmo. 2011 . Perpajakan. Edisi Revisi. Yogyakarta: Andi Offset.

Peraturan Daerah Kabupaten Semarang Nomor 10 Tahun 2010 tentang Pajak Daerah.

Peraturan Daerah Kabupaten Semarang Nomor 12 Tahun 2013 tentang Pajak Daerah.

Peraturan Menteri Pariwisata dan Ekonomi Kreatif Nomor 11 Tahun 2014 tentang Standar Usaha Restoran.

Sunyoto, Danang. 2011. Analisis Regresi dan Uji Hipotesis. Yogyakarta: Center for Academic Publishing Service.

Undang-Undang Republik Indonesia Nomor 28 Tahun 2009 tentang Pajak Daerah dan Retribusi Daerah.

Undang-Undang Republik Indonesia Nomor 23 Tahun 2014 tentang Pemerintahan Daerah.

Ustman, Fathor Rachman. 2015. Panduan Statistika Pendidikan. Yogyakarta: Diva Press.

Yunita. 2013. “Analisis Efektivitas dan Kontribusi Penerimaan Pajak Restoran terhadap Penerimaan Pajak Daerah pada Dinas Pendapatan Daerah Kota Palembang".Jurnal Akuntansi Universitas Bina Darma Palembang. http://digilib.binadarma.ac.id/download. php?id=816. $(20$ April 2017). (Internet) 